\title{
O grupo teatral Gente Nossa e a cruzada social contra os mocambos no Recife (1939)
}

The theatrical group Gente Nossa and the social crusade against the mocambos in Recife (1939)

\author{
Newton Darwin de Andrade Cabral* \\ newton@unicap.br \\ Lúcio Renato Mota Lima** \\ luciorenato75@gmail.com
}

Resumo: O artigo aborda a relação de intelectuais com o sistema de poder, enfatizando mais uma situação em que se fez a tentativa de solucionar conflitos sociais existentes em determinada conjuntura, recorrendo a estratégias de desmobilização social. A análise tem como cenário o período do Estado Novo, particularizado nas disseminações de sua forma de agir, no caso, focando em Pernambuco, no períododa gestão de Agamenon Magalhães. O ator principal é o Grupo de Teatro Gente Nossa, e a trama envolve a luta contra os mocambos, uma vez que a erradicação daquele tipo de moradia era uma das metas do interventor pernambucano. A análise empreendida ajuda a desvendar a utilização de empreendimentos culturais postos a serviço de um projeto político. O artigo evidencia uma importante vinculação: a que se deu entre o regime então vigente e um dos mais sólidos pilares de sua sustentação - a cultura. E, nesta, a manifestação teatral planejada para ser um eficaz veículo de publicidade objetivando a fomentação de um pensamento hegemônico que, por sua vez, visava a justificar as lutas travadas em favor da edificação de uma sociedade ordenada e obediente a valores pré-estabelecidos. Baseado em pesquisas documental e bibliográfica, o estudo não deixa dúvidas de que a atuação do Grupo de Teatro Gente Nossa foi mais um caso que pressupunha a arte instrumentalizada e posta a serviço da consolidação de um modelo social; portanto, não voltada à produção de embevecimentos e fruições estéticas.

Palavras-chave: Arte e política. Teatro pernambucano. Urbanização do Recife

Abstract: The article approaches the relationship of intellectuals to the system of power, emphasizing one more situation, where the attempt is made of solving existing social conflicts in determined conjunctures using strategies of social demobilization. The scene of the analysis is the period of the New State distinguished by the dissemination of its way of acting, focusing in this case on Pernambuco during the administration of Agamenon Magalhães. The principal actor is the theatre group Gente Nossa, and the plot includes the fight against the mocambos, since the eradication of that kind of housing was one of the Pernambuco intervenor's goals. The analysis undertaken helps to unveil the use of cultural enterprises put to the service of a political project. The article proves an important linking: that which took place between the then existing system and one of the most solid pillars of its support-culture. And inside of it, the theatrical manifestation planned to be an efficient vehicle of publicity with the objective of fomentation of a hegemonic thinking which, in its turn, aimed at justifying the fights which were locked in favor of the building of a society commanded and obedient to pre-established values. Based on documental and bibliographical researches, the study leaves no doubt that the activity of the theatre group Gente Nossa was one more case which presupposes art as made use of and put to the service of the consolidation of a social model; therefore, not dedicated to the production of rapture and esthetic enjoyment.

Keywords: art and politics, theatre of Pernambuco, urbanization of Recife

\footnotetext{
*Professor do Curso de História e do Programa de Pós-Graduação em Ciências da Religião da Universidade Católica de Pernambuco (UNICAP). **Mestre em História pela Universidade Federal de Pernambuco (UFPE). Professor no Instituto Profissional Maria Auxiliadora.
} 


\section{Introdução}

O bonde de São Januário/

leva mais um operário/

sou eи que vou trabalhar.

Wilson Batista

Após a Revolução de 1930, o jornalista e dramaturgo Samuel Campelo foi convidado para assumir a direção do Teatro de Santa Isabel (SILVA, 2009. p. 52) ${ }^{1}$. Empossado, decidiu viabilizar um sonho antigo: criar um grupo teatral cuja finalidade era "deixar bem clara a existência real de um 'teatro Pernambucano', realizado sob os mais sólidos princípios de honestidade artística e de sadio idealismo" (ANUÁRIO, 1939). Surgia, assim, o Grupo Gente Nossa, a primeira companhia teatral permanente do estado.

Entre 1931 e 1939, o Grupo Gente Nossa teve uma atuação destacada no cenário artístico pernambucano, ao valorizar autores, atores, técnicos e temas pernambucanos. Além disso, a historiadora Ana Carolina Miranda Paulino da Silva identifica uma filiação entre os propósitos do grupo teatral de Samuel Campelo com o programa do Movimento Regionalista e Tradicionalista do Recife, que havia sido lançado por intelectuais nortistas na década de 20, sob a inspiração de Gilberto Freyre (ALBUQUERQUE JÚNIOR, 2009, p. 100), colocando-se em desacordo com a posição de Joel Pontes, que não via nenhuma aproximação entre os dois movimentos. Para a mencionada historiadora,

Recife ganhou o seu primeiro grupo de teatro permanente, que seguiu a'seu modo' o que acreditava ser moderno, ou seja, um teatro que privilegiou o ator e o autor pernambucano, assim como as manifestações culturais da sua terra. Em toda a sua trajetória, grande foi a influência das ideias freyreanas (SILVA, 2009, p. 167).

No entanto, ao longo do período de sua existência, o grupo passou por várias dificuldades similares às de outras companhias teatrais brasileiras do seu tempo, como a constante saída e entrada de novos componentes, a insuficiência dos recursos financeiros, a ausência de uma regular subvenção estatal e, principalmente, a falta de casas de espetáculos para suas representações, pois o Teatro de Santa Isabel - a virtual "casa" do grupo -, ficava, frequentemente, ocupado por companhias vindas do sul do país ou do estrangeiro, o que facilitava a dispersão do grupo. Além disso, Campelo se magoava com a falta de reconhecimento, principalmente por parte de uma parcela da intelectualidade local, para com o relevante serviço prestado pelo Gente Nossa para o desenvolvimento da arte cênica em Pernambuco (SILVA, 2009, p. 156).

Tais problemas se agravaram no segundo semestre de 1938, o que levou Samuel Campelo a decidir pelo encerramento do grupo teatral, com poucas perspectivas de retorno. A morte dele, no início de 1939, parecia sepultar, definitivamente, o Grupo Gente Nossa.

\section{Agamenon e a educação das massas}

Foi nesse momento de crise aguda que entrou em cena a figura de um inesperado e poderoso mecenas: o Interventor de Pernambuco, Agamenon Magalhães. Sua atuação foi decisiva para a reorganização do Gente Nossa, em 1939. O Interventor, que fora ministro do Trabalho no período do governo con-

\footnotetext{
${ }^{1}$ A historiadora Ana Carolina Miranda Paulino da Silva cita trecho de um livro de memórias dedicado a Samuel Campelo, escrito pelo seu amigo e colaborador, Valdemar de Oliveira, que aponta os predicados que motivaram o convite a ele formulado, pelo novo regime, para assumir o cargo suprareferido: "Tinha todas as qualidades que a Revolução exigia: era técnico de teatro e mentalidade de tenente. Essa mentalidade não adveio de nenhuma força ou influência postiça: era própria do seu caráter e da sua cultura, inconfundíveis como as impressões digitais. Essa mentalidade, um pouco bravia, como convém a quem manda, não a levou ele para o teatro. Para lá levou a mentalidade do companheiro e do animador".
} 
stitucional de Vargas (1934 - 1937) e desfrutava de sua inteira confiança, foi descrito por Manuel Correia de Andrade como um "homem autoritário, enérgico e com grande senso de oportunidade" (JORNAL DO COMMERCIO, 1995, fasc. 12, p. 8). Sendo assim, vislumbrou, no grupo teatral fundado por Campelo, um potencial instrumento de propaganda para o convencimento das massas sobre a correção de uma das suas principais campanhas administrativas: a cruzada social de erradicação dos mocambos.

Em artigo publicado na Folha da Manhã, jornal pertencente ao Interventor, de 14 de fevereiro de 1939, Magalhães escreveu sobre a morte de Campelo: "O teatro nacional perdeu, com a morte de Samuel Campelo, um dos seus grandes animadores" (ANUÁRIO, 1939, p. 15). Manifestou, ainda, que o teatro poderia ser utilizado como um instrumento fundamental na educação das massas, ao contrário do cinema, visto como elemento desagregador tanto da infância quanto do operariado, porque atuaria "disciplinando as tendências e dando ao gosto pela arte um sentido moral ou educativo, colocando, enfim, os brasileiros, dentro do Brasil” (ANUÁRIO, 1939, p. 15), o que deveria ser uma função do Estado, pois "o Estado Novo tem como programa a coordenação de todos os valores educacionais. O teatro é um criador de emoções. Emoções de arte, emoções de vida, exaltação dos motivos nacionais" (ANUÁRIO, 1939, p. 15).

Vale destacar que a educação das massas constituía um dos pilares do programa da ditadura varguista, cujo objetivo era a promoção dos valores considerados positivos e salutares pelo regime, fundamentados nos conceitos de Pátria, Família, Trabalho e Fé. Ao mesmo tempo que esperava a assimilação de tais valores, o governo almejava neutralizar o contágio das massas por ideologias consideradas como "exóticas e dissolventes" pela ditadura: o liberalismo e o bolchevismo, que somente poderiam provocar o desequilíbrio da ordem social (ALMEIDA, 2001, p. 42).

Em tal ação pedagógica, o governo empregava importantes instrumentos de divulgação, como a escola, a imprensa e o rádio. Mas o potencial do teatro não foi desprezado. Como salienta Angélica Ricci Camargo, embora a questão do teatro tenha recebido menor atenção da historiografia sobre as políticas culturais do primeiro governo Vargas (1930 - 1945), foi naquele período que foram criados órgãos administrativos com o objetivo de fomentar a atividade teatral: primeiramente a Comissão de Teatro Nacional, que foi substituída pelo Serviço Nacional de Teatro, ambos subordinados ao Ministério de Educação e Saúde, então dirigido por Gustavo Capanema (2011, p. 3).

Sob a ótica de vários artistas e produtores teatrais, Getúlio Vargas era considerado um patrono do desenvolvimento das artes cênicas, pois foi ele o autor da primeira lei regulamentadora dos direitos autorais e da profissão dos atores, em 1928, quando exercia o mandato de deputado federal. De acordo com Camargo, "a chegada de Vargas à presidência da República provocou uma maior movimentação da classe teatral, com o fim de conquistar um amparo definitivo para a área” (2011, p. 5). Para muitos do meio, a criação do Serviço Nacional do Teatro era a viabilização desse amparo. $^{2}$

A dimensão educativa do teatro, particularmente em relação às massas, já fazia parte do ideário do seu

\footnotetext{
${ }^{2}$ Nas páginas iniciais do Anuário do Gente Nossa constam fotos e comentários elogiosos ao auxílio prestado por Getúlio Vargas, Gustavo Capanema e Agamenon Magalhães. Na legenda referente à fotografia de Vargas está escrito: "Presidente Getúlio Vargas, grande amigo do Teatro Nacional, que concedeu ao Grupo Gente Nossa, uma subvenção anual”.
} 
fundador, Samuel Campelo. Como informa Ana Carolina Miranda, com base na análise da tese "Teatro como Diversão e Cultura", Campelo, "guiado por um discurso que de alguma forma privilegiava as camadas menos abastadas, trouxe para o Teatro Santa Isabel um público popular, que deveria ser educado da melhor forma: através da arte" (SILVA, 2009, p. 19).

Após sua reorganização, no início de 1939, a atuação pedagógica do grupo teatral foi reforçada, como enaltece o editorial publicado pelo Jornal do Commercio, do dia 2 de abril, sob o título "Uma obra de elevado sentido social", no qual foi ressaltado o caráter indispensável do teatro na obra de formação da infância e das massas operárias:

O trabalho que o 'Grupo Gente Nossa' vem realizando, em favor do teatro nacional, está a merecer um registro de simpatia e aplauso, tendo-se em vista, sobretudo, o elevado cunho educacional que vem revestindo sua reentrada no campo das atividades culturais de nossa terra... Em verdade, na obra da educação, não há como prescindir do teatro como fator precipuo da formação intelectual da infância e como colaborador de maior eficácia, na obra de integrar a massa no plano de seu papel construtor da nossa grandeza de amanhã (ANUÁRIO, 1939, p. 22).

Para Agamenon, a conjuntura se apresentava favorável para a exploração do potencial pedagógico da arte dramática, pois cabia ao governo de Pernambuco, naquele momento, convencer os principais atingidos pela campanha contra os mocambos - os trabalhadores recifenses -, da justeza da sua ação.

De acordo com a historiadora Maria das Graças Andrade Ataíde de Almeida, o projeto de erradicação dos mocambos se inseria no programa modernizador de
Agamenon, que pretendia equiparar o Recife à capital do Brasil. Para ela, nesse sentido,

\section{uma das primeiras medidas da Interven- toria foi formular um plano de remodela- ção da cidade segundo o qual a miséria - em todas as suas nuances - deveria ser extirpada, porque por ela se expressava o retrato da feiura do Recife. A proposta de modernização concentrava-se na ideia de sanear, higienizar e embelezar a cida- de (ALMEIDA, 2001, p. 125).}

Verificava-se, mais uma vez, na história brasileira, a formulação e execução de um projeto de remodelação dos grandes centros brasileiros pautado na demolição das habitações populares, por serem estas consideradas como símbolos do atraso, do feio, da doença e da criminalidade que imperavam no país, o que, na prática, promovia a exclusão dos pobres do centro das capitais brasileiras e seu deslocamento forçado para os subúrbios ${ }^{3}$. Vale, ainda, salientar que Graça Ataíde identificou a filiação ideológica entre a remodelação urbanística proposta para o Recife com o projeto arquitetônico do III Reich, executado em Berlim (ALMEIDA, 2001, p. 125).

A campanha para a erradicação dos mocambos, da Interventoria de Agamenon Magalhães, tinha como órgão de coordenação a "Liga Social Contra o Mocambo", vinculada à Diretoria de Reeducação e Assistência Social (DRAS), da Prefeitura do Recife. Antes de iniciar a campanha, Agamenon nomeou, em 1938, uma Comissão Censitária que realizou um inédito levantamento sobre o número de mocambos existentes na cidade $\mathrm{e}$ que revelou "a extensão do 'mal que assolava a planície recifense' e a necessidade de uma intervenção urgente do Estado sobre a questão da habitação popular" (LIGA, 1938).

\footnotetext{
${ }^{3}$ Sobre o assunto, ver CHALHOUB, 1996 e CARVALHO, 2002.
} 
Depois de realizado o levantamento, a Liga Social Contra o Mocambo pôs em execução um plano de construção de casas econômicas, segundo os seguintes critérios: a) casas para fins de assistência social; b) casas para operários sindicalizados e contribuintes dos Institutos de Previdência e Caixas de Pensões do Ministério do Trabalho; c) casas para candidatos de todas as atividades profissionais (LIGA, 1938).

De acordo com Jacqueline Cássia Pinheiro Lima, que traçou um paralelo entre as reformas urbanas em curso, concomitantemente, no Rio de Janeiro e no Recife, no período do Estado Novo, a modernização social das áreas consideradas carentes deve ser entendida em consonância com a política de higienismo social que implicava readaptação e reeducação dos moradores que eram transferidos. O objetivo maior era formar cidadãos segundo o ideário que se tentava implementar (LIMA, 2004).

Fica evidente, portanto, que não era apenas contra a moradia do mocambo que se debatia a campanha movida pelo governo do estado de Pernambuco. Ela era contrária ao estilo de vida classificado como inadequado e perigoso pelo ideário estadonovista e favorável à sua substituição por valores consagrados, como o trabalho, a fé, o patriotismo e o respeito às autoridades.

\section{O grupo Gente Nossa e o teatro social}

Por intermédio do prefeito do Recife, Novaes Filho, Agamenon convidou o jornalista e médico Valdemar de Oliveira, amigo e colaborador de Samuel Campelo, para ser o novo diretor do Teatro de Santa Isabel. Cabia, também, a Valdemar, empenhar-se na obra de reorganização do Grupo Gente Nossa.
Ressurgido sob patrocínio oficial, o Gente Nossa passou a colaborar estreitamente com as ações administrativas do Interventor de Pernambuco: "Abordando, depois, o gênero de teatro social, fez encenar diversas peças de cunho educativo para operários, ao tempo que, em uma delas [Mocambo], colaborava com o governo do Estado em sua campanha contra o mocambo" (ANUÁRIO, 1939, p. 22).

Portanto, como foi dito acima, o Grupo Gente Nossa, após sua reorganização, deu relevo ao chamado "teatro social", que tinha como público-alvo o operariado recifense, especialmente àquele associado aos Centros Educativos Operários, que se espalhavam por 12 bairros industriais da cidade, como Afogados, Água Fria, Santo Amaro, Campo Grande etc. (MÉLO FILHO, 2006, p. 49); essa aproximação foi feita sob os auspícios da Diretoria de Reeducação e Assistência Social, à qual estava vinculada a Liga Social Contra o Mocambo, e que era dirigida pelo militante católico, membro da Congregação Mariana ${ }^{4}$ e fundador dos Centros Educativos Operários do Recife, José Milton de Pontes (MÉLO FILHO, 2006, p. 48). É importante frisar que Agamenon institucionalizou os Centros Educativos Operários, também os vinculando ao DRAS.

A criação dos Centros Educativos Operários foi anterior à implantação do Estado Novo. De acordo com Manuel Correia de Andrade, Agamenon havia procurado aglutinar em torno de si um grupo de sindicalistas, com o conhecimento e apoio do Ministério do Trabalho, com o objetivo de neutralizar e perseguir militantes socialistas, anarquistas e democratas do movimento sindical. Objetivando complementar essa ação sindical "ele organizou os Centros Educativos

\footnotetext{
${ }^{4}$ Após terminado o Concílio de Trento, em 1563, a Igreja preocupou-se com o como fazer passar as decisões conciliares para a vida cotidiana dos fiéis, levando-os a compreenderem a necessidade de manterem certas práticas, como se confessarem com regularidade, comungarem com frequência e vene-

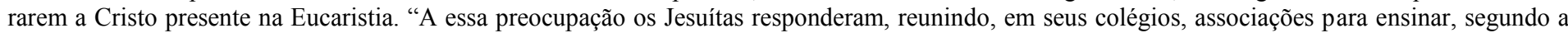
diversidade dos grupos, os princípios do Concílio. Nessa perspectiva, insere-se o papel das Congregações Marianas” (CABRAL, 2009, p. 167).
} 
Operários que desenvolviam uma educação baseada nos princípios católicos da bula RerumNovarum de Leão XIII" (JORNAL DO COMMERCIO, 1995, fasc. 12, p. 8). Embora não se apresentasse como um católico praticante, Agamenon, assim como todo o regime do Estado Novo, recebeu durante seu governo, significativo apoio da Igreja Católica, sobretudo através dos Congregados Marianos que atuavam a partir do Colégio Nobrega ${ }^{5}$ (fundado pelos Jesuítas, no Recife, em 1917).

Não era a primeira vez que os princípios contidos na RerumNovarum eram aplicados ao operariado pernambucano. Entre o final do século XIX e início do XX, o industrial católico, Carlos Alberto de Menezes, já havia empreendido a iniciativa de promover, entre os operários da Companhia Industrial Pernambucana, composta pela Fábrica de Tecidos de Camaragibe e pela Usina João Alfredo, em Goiana, os ideais propostos na Encíclica de Leão XIII, tendo, inclusive, construído a Vila Operária de Camaragibe, conforme os padrões de higiene vigentes, e que teve suas condições sanitárias aprovadas por uma comissão médica, chefiada pelo sanitarista Otávio de Freitas, e ligada ao Primeiro Congresso Médico de Pernambuco, realizado em 1909. Vale salientar que o projeto de Menezes também apresentava uma fundamentação moralizadora visando à reeducação dos operários, objetivando, ao mesmo tempo, tanto torná-los mais eficientes e produtivos quanto bons cristãos e imunes à influência das ideias socialistas (LIMA, 2009).

O estudo da relação entre a Igreja Católica e o Estado Novo, especificamente em Pernambuco, indica a presença de vários leigos católicos, principalmente pertencentes à Congregação Mariana da Mocidade
Acadêmica (CMMA), em cargos importantes do governo, como a Diretoria da Fazenda, dirigida por Manuel Lubambo, a Diretoria de Educação, dirigida por Nilo Pereira, e a Diretoria de Reeducação e Assistência Social, ocupada por José Milton Pontes (MÉLO FILHO, 2006, p. 48), que haviam sido educados sob a influência do ferrenho discurso anticomunista do padre Antonio Paulo Cyríaco Fernandes, diretor da CMMA (CABRAL, 2009). A escolha de tais elementos para a composição da Interventoria de Pernambuco, coadunava-se com o combate incansável à propagação do comunismo, um dos pilares da política de Agamenon. De acordo com Cabral,

a guerra contra o comunismo foi um grande empenho do Pe. Fernandes e da CMMA, levando-o a vangloriar-se do sucesso obtido pelos seus Congregados Marianos na luta empreendida com tal finalidade, na década de 1930. Isso, explica, parcialmente, por que a partir dos quadros da Congregação, foram recrutados alguns dos nomes que fizeram parte do secretariado de Agamenon Magalhães, quando interventor em Pernambuco, a partir de 1937. Dentre esses nomes, destacamos Manuel Lubambo, na Secretaria da Fazenda, Arnóbio Tenório, na Secretaria de Governo, Nilo Pereira, em Imprensa e Educação e Apolônio Sales, na Secretaria de Agricultura (2009, p. 171-172).

Acrescentamos à lista supramencionada o nome do fundador dos Centros Educativos Operários e chefe da Diretoria de Reeducação e Assistência Social, José Milton de Pontes. De acordo com Mélo Filho, a Diretoria surgiu em 1935, “com a finalidade de ser uma barreira à intensa propaganda do período" (2006, p. 48). Conforme já afirmado, Agamenon institucionalizou os Centros, vinculando-os ao DRAS. Além do combate ao comunismo, cabia àquela Diretoria oferecer "o incre-

\footnotetext{
${ }^{5}$ Para podermos aquilatar a dimensão das Congregações Marianas, remetemos a um jesuíta que escreveu sobre a história de tais instituições no Brasil: "Enquanto outras Ordens e Congregações Religiosas fundadas no século XVI, e mesmo muitas das já antes existentes, tinham suas Ordens terceiras ou filiações semelhantes, a dinâmica da espiritualidade inaciana floresceu nas Congregações Marianas” (MAIA, 1992, p. 50).
} 
mento de práticas esportivas, o incentivo aos serviços médicos nos bairros operários e o acréscimo de oferta de ensino primário, profissional e doméstico para adultos" (MÉLO FILHO, 2006, p. 49).

Os Centros estavam divididos em quatro departamentos: a) Instrução; b) Beneficência e Defesa; c) Cultura Física e Artística; d) Estudos. Em relação ao último departamento, responsável pela formação dos dirigentes dos Centros, merece destaque o local onde se realizava, semanalmente, a reunião dos seus integrantes, ou seja, instrutores, professores, agentes sociais, mestres, contramestres e membros dos conselhos operários: o Teatro do Colégio Nóbrega, pertencente aos jesuítas, e sede da Congregação Mariana do Recife (MÉLO FILHO, 2006, p. 68).

Novamente chamamos a atenção para o fato de que o DRAS também comportava a Liga Social Contra o Mocambo, implicando ser o mocambo um inimigo a ser combatido e eliminado. Assim, entendemos que a Interventoria de Pernambuco arregimentou o teatro social do Grupo Gente Nossa, o qual efetuou o papel de veicular propaganda de demonização do mocambo, da mesma forma que o fazia a imprensa, responsabilizando -o pelos males sociais dos seus moradores e enaltecendo a ação do governo na sua destruição:

\section{A imprensa encarregou-se de veicular a ideia de que o mocambo era o elemento fomentador de pobreza, infelicidade $e$ crimes. A miséria era relativizada ao mocambo. Portanto, identificava-se na erradicação do mocambo a emergência da felicidade, da alegria, da higiene, do trabalho e da ordem (ALMEIDA, 2001, p. 129).}

É o que podemos verificar ao analisarmos o texto da peça "Mocambo", de Valdemar de Oliveira e Filgueira Filho.

\section{A peça "Mocambo"}

A peça propagandística "Mocambo", de Valdemar de Oliveira e Filgueira Filho, foi a que alcançou o maior número de representações na história do Grupo Gente Nossa, com 40 encenações no ano de 1939 (ANUÁRIO, 1939). Escrita às pressas, contava, inclusive, como cenário, no seu segundo ato, com um autêntico mocambo demolido pela Secretaria de Segurança Pública.A estreia da montagem foi no dia 2 de agosto de 1939, no Teatro de Santa Isabel; depois, ela foi exibida nos diversos Centros Educativos Operários. ${ }^{6}$

No dia da estreia, um dos autores, Filgueira Filho, pronunciou um discurso de celebração do oitavo aniversário do Gente Nossa, destacando a atuação do grupo em prol do desenvolvimento do teatro pernambucano e o apoio a ele dado tanto pelo Interventor Agamenon, quanto pelo Prefeito Antônio Novaes que, “dotados pela esclarecida visão dos seus governos amparam o teatro que fazemos, numa afirmativa das verdadeiras diretrizes do Estado Novo" (ANUÁRIO, 1939, p. 25-26).

O enredo da peça, dividida em três atos, desenvolve-se em torno dos operários da fábrica de tecidos "Horizonte", onde os negócios não iam bem, devido à insatisfação dos operários com as más condições de trabalho. A filha do proprietário, Laís, tentava, inutilmente, convencer o pai a reconhecer os direitos trabalhistas dos operários e promover melhorias nas suas condições de vida, como forma de salvar a fábrica, uma vez que problemas de faltas ocasionadas por doenças, e a baixa produtividade, impediam o lucro da empresa. De acordo com a personagem, "o operário precisa ser bem tratado. É uma máquina como as outras. Asseio,

\footnotetext{
${ }^{6}$ A primazia coube ao Centro Educativo Operário de Santo Amaro.
} 
combustível - de tudo isso ela necessita para funcionar bem. Se as máquinas, de ferro, de cobre, de aço, se gastam, quanto mais a máquina humana!” (OLIVEIRA; FILGUEIRA FILHO, 1939, p. 14).

No entanto, seus esforços eram ardilosamente sabotados pelo antagonista da trama: o personagem $\mathrm{Eu}-$ gênio, que representava a figura do perigoso agitador social, infiltrado na fábrica com o intuito de promover o confronto de classes entre operários e patrões. Eugênio fazia jogo duplo. Fingia estar ao lado do patrão, mas, sorrateiramente, incitava a revolta dos operários contra sua condição.

Laís representa, na peça, a figura do proprietário atualizado com as mudanças promovidas pelo Estado Novo. No mesmo diálogo citado, Eugênio questiona desafiadoramente a Laís

Eugênio: "A senhora anda lendo coisas que não devia ler.

Lais: "E o senhor devia ler coisas que ainda não leu... As leis trabalhistas"...

Eugênio: "Que leis? A lei, aqui, deve ser seu pai!"

Laís: "E é por isso que as coisas chegaram a este ponto. Ele não atende a nada, não quer ouvir ninguém... a não ser o senhor!"

Eugênio: "E queria a senhora que ele ouvisse o operário?"

Laís: "Claro! O operário é tudo: é a mão de obra. É a alma da fábrica. É a força motora de tudo isso".

Eugênio: "A força é a máquina".

Laís: "Mas, tire-lhe o operário e ela não funcionará. Será um molhe de ferro e de aço, parada, inerte, à espera do braço vigoroso do operário, que a fará encher de vida a fábrica inteira.

Eugênio: "Muito bonito para ser proferido numa reunião proletária!"

Lais: "Mais bonito ainda para ser proclamado numa assembleia de patrões" (OLIVEIRA; FILGUEIRA FILHO, 1939, p. 14-15).
A tensão entre Eugênio e Laís era acentuada pela atração que ela sentia pelo personagem do operário Carlos, o qual se sobressai na trama da peça por encarnar a representação do trabalhador ideal, conforme os moldes do Estado Novo: honesto, trabalhador, dócil, conciliador e legalista. O protagonismo de Carlos no enredo fica evidenciado pela afeição que desperta na filha do patrão, embora este não lhe dê esperanças de ser correspondida, pois já estava comprometido com a filha de outro operário da fábrica, Lourenço. Carlos procura atuar como mediador do latente conflito de classes dentro da fábrica, principalmente após a entrada em cena de uma comissão de operários insatisfeitos, composta por Lourenço e Amaro, que decidiram apresentar uma pauta de reivindicações ao proprietário da fábrica, o Sr. Guedes, um homem acometido pela neurastenia. Dentre as principais solicitações constavam o aumento imediato dos salários, o pagamento do seguro contra acidentes e, principalmente, a construção de uma vila operária que pudesse retirá-los da indigna condição de moradores de mocambos. O espírito conciliador de Carlos fica evidente no diálogo: "Que diabo!... Tudo se pode conseguir com brandura. Os tempos estão mudando" (OLIVEIRA; FILGUEIRA FILHO, 1939, p. 33). Contudo, suas boas intenções são prejudicadas pela ação desestabilizadora de Eugênio.

$\mathrm{O}$ encontro entre o industrial Guedes e a comissão operária foi marcado pela tensão e má vontade do patrão. Depois de solicitar o aumento dos salários e o pagamento do seguro contra acidentes, os operários solicitam a construção da vila operária para abrigá-los. A difícil vida dos moradores nesse tipo de habitação popular é descrita, de forma comovente, pelo personagem Lourenço.

É o mocambo, patrão. A mocambaria do pessoal está caindo toda. Estamos quase dentro do mangue. Chove dentro do mangue. Chove dentro do mocambo. Nas noites de inverno, é como se se estivesse 
na rua: a água entra pelos buracos da palha e encharca a rede. É um frio medonho. O chão fica empoçado d'água suja. O barro vira lama. E a gente tem de aguentar aquilo tudo, pedindo a Deus que o tempo melhore. Isto quando a cheia não leva o mocambo e os trastes vão boiando, rio abaixo! $O$ vento chia na palha, como se fosse gente, arrepiando a coberta. $E$ as goteiras pingando, pingando, pingando... A água entra pela porta da frente e atravessa a casa toda, numa enxurrada. E de manhã quando a gente se levanta, o rio está na beira da porta. Só falta vir tudo abaixo. Os enxameis [sic], fica tudo penso. A gente fica ilhada, sem poder sair. E se sair é por dentro da lama, até chegar no asfalto. A família fica em casa, presa, como se fosse condenada. Quando a trovoada ronca, os caranguejos saem dos buracos e acabam tomando conta do mocambo. Em tempo de lua, os maruins encalombam o corpo todo. Não há quem aguente. E é tudo doente e amarelo, tudo parecido uns com os outros, barrigudos $e$ emperrados. Não se pode nem plantar um pé de feijão: tudo é chiqueiro, o fundo da casa é só lama, os porcos fuçando e os urubus descendo, para aproveitar o que sobra. Aquilo não é lugar para ninguém morar. Já perdi ali um filho. Minha mãe foi com uma febre para o hospital $e$ lá se acabou. E minha menina mais moça está seguindo o mesmo caminho, doente do peito, na tipoia. É tudo assim. Não há casa onde não tenha um doente. Quem vive num mocambo, não pode ter saúde (OLIVEIRA; FILGUEIRA FILHO, 1939, p. 47-48).

Contudo, o patrão se mostra irredutível e expulsa a comissão do seu escritório. Laís ainda tenta, mais uma vez, convencê-lo do seu comportamento anacrônico, baseando sua argumentação no dever patriótico que, a seu ver, o industrial moderno devia ter: o de atender às necessidades dos seus operários. Questionada sarcasticamente por Eugênio, Laís retruca, reafirmando os valores propagados pelo Estado Novo: "Sim! Porque é um dever de patriotismo a valorização do homem, como elemento de trabalho e de produção. E extinguir o mocambo é valorizar o homem da nossa terra". (OLIVEIRA; FILGUEIRA FILHO, 1939, p. 52). Pressionado, o neurastênico Guedes decide vender a fábrica para outro industrial, o Castro, cuja mentalidade se coadunava com as diretrizes defendidas pelo Estado Novo.

No segundo ato, a trama se desenrola no mocambo de Lourenço, onde a situação beira a indigência. Naquele espaço exíguo e insalubre moram Lourenço e a esposa, que costura para fora a fim de melhorar a renda familiar; a filha mais velha, Das Dores, noiva de Carlos e que se encontra desempregada; a filha mais nova, que se encontra presa a uma cama, consumida pela tuberculose; dois filhos pequenos, que vestem andrajos e vivem brincando na lama do mangue sem estudar; e Severino, amigo da família e faxineiro da "Horizonte". A alimentação básica da família é o caranguejo, obtido diariamente por Severino no mangue.

Nesse cenário desolador, Lourenço recebe a visita de Eugênio e Amaro, que discutem a situação da fábrica após a sua venda para o industrial Castro. Embora o novo patrão viesse referendado, pois desfrutava de boa reputação no tratamento dos seus operários, Eugênio e Amaro, inoculados com o germe da luta de classes (conforme discurso vigente), tentavam convencer Lourenço da inutilidade de esperar mudanças na sua precária condição. Ludibriado por Eugênio, Lourenço resolve, ingenuamente, guardar algumas caixas contendo bombas que, posteriormente, seriam utilizadas por Eugênio e Amaro em futuras ações de sabotagem.

Entretanto, a família operária recebe a inesperada visita do Sr. Castro que, em visita aos mocambos dos seus novos subalternos, promete o aumento dos ordenados, a aplicação da legislação trabalhista estadonovista e, principalmente, a construção de uma vila operária: "Não quero mais um mocambo destes em pé. São verdadeiras pocilgas!" (OLIVEIRA; FILGUEIRA FILHO, 1939, p. 97-97). Percebendo as boas intenções do Sr. Castro, Lourenço tenta desfazer-se do arsenal escondido em sua casa, mas é surpreendido pela in- 
vasão do seu mocambo pela polícia, que encontra o material subversivo e o leva preso.

No último ato, a situação é completamente diferente. O cenário é a nova casa onde reside a família operária, na vila operária da fábrica "Horizonte". Carlos havia sido promovido pelo novo chefe ao cargo de mestre de estamparia e tinha casado com Das Dores e tido seu primeiro filho. Mostrava-se realizado na nova casa. Apesar de humilde, o ambiente era limpo, decente, arejado e dotado de terreno no qual o operáriomodelo - segundo as perspectivas do Estado Novo plantava sua horta. Portanto, uma condição oposta à vivenciada anteriormente no sujo mocambo. As crianças estudavam na escola da fábrica e a alimentação era agora diversificada. A felicidade familiar só não era completa por duas razões: a morte da menina tuberculosa e a permanência de Lourenço na cadeia. Satisfeitos, saudáveis e esperançosos, os personagens atingem a plenitude da alegria após a libertação de Lourenço.

O clímax da peça é o confronto entre os integrantes da família e o vilão da trama: o agitador Eugênio. Este, após um período desaparecido, resolve visitar a família operária a quem fizera tanto mal. No diálogo travado entre Carlos e Eugênio, o primeiro enaltece as ações e valores estadonovistas:

Carlos: "Qual nada. As coisas melhoram dia a dia. Castro Machado é outro homem. Agora gozamos férias todo ano, temos seguros contra acidentes, indenização, dinheiro para enterro e para luto...

Eugênio: "Mas, quem deu isso não foi Castro Machado. Ele faz tudo isso por que a lei o obriga".

Carlos: "Mas o outro dizia que não tinha lei. Que a lei era ele".

Eugênio: "Orgulho de burguês...

Carlos: "Temos tudo. O governo vem facilitando as coisas. A vida melhora..."
Eugênio: "São as célebres leis trabalhistas (sorri, irônico)".

Carlos: "E são elas mesmo. Ainda outro dia, o dr. Xavier disse que as leis do Brasil são as melhores para os operários..." (OLIVEIRA; FILGUEIRA FILHO, 1939, p. 137).

O diálogo supracitado evidencia que o principal responsável pelas conquistas dos operários era o regime do Estado Novo, demonstrando que os valores apregoados por elementos como Eugênio eram nocivos e desnecessários. Carlos, para surpresa de Eugênio, expulsa-o do novo lar:

\section{Eugênio: "Bota-me para fora?" \\ Carlos: "Boto. Porque não quero perder mais tempo em ouvi-lo. Estou farto. Você vive explorando a boa-fé dos operários, enganando-os com essa parte de dizer que é nosso amigo... Mas, aqui, não há mais lugar para vocês..." \\ Eugênio: "Para vocês?" \\ Carlos: "Para vocês... sim. Porque não é um nem dois a nos encher os ouvidos de cantigas, atrapalhando a nossa vida... Como se nós fossemos eternamente bone- cos ou meninos que se engana prometendo doce... Repito: aqui não há mais lugar para vocês! Deixem-nos em paz! Em paz, ouviu? Em paz!” (OLIVEIRA; FILGUEIRA FIL- HO, 1939, p. 139).}

Assim, no plural, as ideias perniciosas representadas por Eugênio são veementemente rechaçadas pelo honesto, trabalhador e respeitador das autoridades, Carlos. A palavra "paz" é três vezes repetida como se fora uma palavra de ordem, que devesse ser introjetada pelos demais operários. O diálogo remete ao ideal da paz social proposta na RerumNovarum. Eugênio ainda indaga: "Mas, por que isso tudo?" (OLIVEIRA, FILGUEIRA FILHO, 1939, p. 139). Ao que responde Carlos, ressaltando o valor do trabalho:

Por que? Veja esta casa! É minha, minha, ganha com o suor do meu rosto! (orgulhoso, abrindo os braços, como querendo abarcar a casa toda) Minha casa! Aqui está minha mulher, está meu 
filho, está a minha gente, que eu defenderei até a morte com a ajuda de Nosso Senhor! (aponta o quadro do Coração de Jesus) Ele vela por nós. Veja estas mãos! Estão sujas de terra, como as suas nunca estiveram! Temos terra, agora, para plantar e para colher! Você não sabe que alegria isto dá! Você não sabe o que é isto: cavar a terra... (OLIVEIRA; FILGUEIRA FILHO, 1939, p. 140).

A peça conduz à percepção de que somente o trabalho, a aliança entre os patrões e operários e, sobretudo, o apoio governamental poderiam contribuir para uma transformação da vida dos operários. A chegada de Lourenço apenas reforça o discurso enaltecedor dos valores apregoados pelo governo:

Que é que vocês chamam de liberdade? Lourenço: É uma coisa que vocês exploram: a liberdade de fazer mal, de perseguir, de ofender, de desgraçar uma familia inteira! Não! Isso não é liberdade! Liberdade é poder respirar o ar puro do nosso lar, poder viver com os nossos filhos, andar pela rua de cabeça erguida e trabalhar! Trabalhar para ganhar o pão de cada dia! Isto sim, é a liberdade que basta ao operário! (OLIVEIRA; FILGUEIRA FILHO, 1939, p. 142).

Expulsos Eugênio e suas más ideias, Carlos abre os braços num gesto de alegria e acolhimento, e exclama: "Minha casa! Minha gente!" (OLIVEIRA; FILGUEIRA FILHO, 1939, p. 143).

\section{Consideações finais}

Em novo artigo, Agamenon manifestou a satisfação com o resultado:"Quem assistir àquele drama, deixará o teatro com um sentimento. Sentimento de solidariedade social. Deixará o teatro com uma resolução. A resolução de ajudar o governo de acabar com o mocambo" (ANUÁRIO, 1939, p. 49).

Vale salientar que a encenação de "Mocambo" não esgotava o objetivo de utilização do teatro como mecanismo para a educação das massas. Um concurso de "peças operárias" foi realizado, novamente sob o patrocínio da Reeducação Social. A intenção era ampliar a atuação do Grupo Gente Nossa como instrumento propagador do discurso estadonovista para o operariado pernambucano.

O edital do concurso é revelador com relação às orientações dirigidas aos possíveis interessados, sobre os objetivos ideológicos dos textos a serem enviados: "Os originais serão destinados a um público de operários, com o fim não só de recreação sadia como, principalmente, de educação" (ANUÁRIO, 1939, p. 44). Sobre os valores que deveriam ser transmitidos nas encenações, identifica-se uma evidente convergência com os ideais propostos pelo discurso governamental voltado para a classe operária: a) a nobreza do trabalho; b) a economia do lar; c) o combate às doutrinas malsãs; d) a luta contra o divórcio; e) a sagrada instituição da família (ANUÁRIO, 1939, p. 44).

Encontramos com relação ao item "c" do edital, uma ressalva que merece ser destacada:

\begin{abstract}
Nas peças que abordarem o assunto do item c, evitar-se-á que, ao expor a doutrina que se quer combater, possa tal ou qual cena possuir efeito contrário sobre a plateia, prestando-se a uma interpretação tendenciosa, se considerada isoladamente do entrecho. A mesma restrição se aplica, de um modo geral, às peças que abordarem os temas dos demais itens (ANUÁRIO, 1939, p. 44).
\end{abstract}

O que nos leva a indagar se estaria a Diretoria de Reeducação e Assistência Social precavendo-se contra possíveis mensagens subliminares dos autores teatrais visando a obter um efeito contrário ao alcançado pelo governo através das suas peças doutrinárias?

Mais uma vez, em outro artigo, Agamenon reconhece o papel educativo do teatro e ressalta, enfaticamente, tanto os valores que o Estado Novo procura incutir por meio da arte cênica quanto as más doutrinas que procura combater: 
O teatro é, portanto, uma grande escola. Escola que transmite às multidões impressões que perduram, que ficam no subconsciente, e que vão influir na conduta social ou política de milhares de espectadores. Ai está a razão por que o meu governo tem procurado fazer do teatro uma fonte de emoções sadias... A Diretoria de Reeducação e Assistência Social acaba de organizar, de acordo com o Grupo Gente Nossa, um concurso de peças teatrais para operários, não só com o fim recreativo, como educacional. A dignidade do trabalho, o combate às doutrinas dissolventes, a economia do lar, a estabilidade da família, o amor à pátria, o combate decisivo às forças anárquicas desintegradoras da nação, como o divórcio, o comunismo, o laicismo, serão os motivos das peças" (ANUÁRIO, 1939, p. 46).

A direção do Gente Nossa saiu à procura de alguns industriais da cidade oferecendo, a baixo preço, a representação das peças aos operários. A Diretoria de Reeducação e Assistência Social também foi procurada pela direção do grupo teatral, a fim de financiar a reconstrução de algumas casas de diversão que, nos subúrbios, estavam em estado precário de conservação. Além dos Centros Educativos, o prefeito Novaes Filho também mencionou a aproximação do grupo teatral junto aos Círculos Operários do Padre Costa Carvalho.

Durante aquele período de colaboração estreita, o Gente Nossa recebeu algumas subvenções dos governos municipal, estadual e federal: Agamenon concedeu uma subvenção mensal de 2 contos de réis, além do auxílio para uma excursão ao Ceará. O prefeito pagou a folha do pessoal externo ao Santa Isabel, durante os espetáculos realizados pelo grupo e decretou a isenção de algumas taxas. No entanto, mesmo cumprindo tal papel pedagógico, o grupo não sobreviveu por muito tempo. Valdemar de Oliveira declarou que "o Grupo já não estava tão bem e ia desaparecendo sem que ninguém percebesse" (SILVA, 2009, p. 164). As fontes disponíveis aos autores não deixam claro o motivo desse encerramento.

O programa da Liga Social Contra os Mocambos não conseguiu atingir, satisfatoriamente, seus objetivos. De acordo com Manuel Correia de Andrade,

o programa pecava pelo fato de não terem os moradores dos mocambos os recursos e as rendas necessárias para pagar e manter as habitações, e também porque os afastava do habitat natural que era favorável à obtenção de alimento diário e, ainda mais, aterrando os alagados conquistou grandes áreas ao leito maior do rio Capibaribe contribuindo para que as suas cheias fossem muito mais danosas à população ribeirinha, atingindo até os bairros de classe média (JORNAL DO COMMERCIO, 1995, fasc. 12, p. 9).

A Liga Social Contra o Mocambo foi, depois de 1945, reformulada e passou a ser denominada "Serviço Social Contra o Mocambo". Entre 1939 e 1945, demoliu 14.597 mocambos, enquanto 6.173 unidades foram construídas. Estima-se que $1 / 4$ da população total da cidade do Recife foi deslocada durante as ações do programa (LIGA, 1938). 


\section{Referências bibliográficas}

ALBUQUERQUE JÙNIOR, Durval Muniz de. A invenção do Nordeste e outras artes. São Paulo: Cortez, 2009. ALMEIDA, Maria das Graças Andrade Ataíde de. A construção da verdade autoritária. São Paulo: Humanitas/ FFLCH/USP, 2001.

ANDRADE, Manuel Correia de. Pernambuco imortal. Recife: Jornal do Commercio, Fascículo 12,1995.

ANUÁRIO do Grupo Gente Nossa. Recife: s.n., 1939.

CABRAL, Newton Darwin de Andrade. Memórias de um cotidiano escolar: Universidade Católica de Pernambuco, 1943 - 1956. Recife: Fundação Antônio dos Santos Abranches, 2009.

CAMARGO, Angélica Ricci. O teatro em questão: um balanço sobre as experiências da Comissão e do Serviço Nacional do Teatro. In: II Seminário Internacional de Políticas Culturais. Salvador, setembro 2011. Textos completos. Salvador: Fundação Casa de Rui Barbosa, 2011. p. 1-12. (Comunicação).

CARVALHO, José Murilo de. Os bestializados. São Paulo: Companhia das Letras, 2002.

CHALHOUB, Sidney. Cidade febril: cortiços e epidemias na Corte imperial. São Paulo: Companhia das Letras, 1996.

LIGA social contra o mocambo (PLANTA/PROJETO). Recife: Editora SSCM (Biblioteca do Arquivo Público Jordão Emerenciano), 1938. Disponível em: http://www.urbanismobr.org/bd/documentos.php?id=156. Acesso: 06 julho 2016.

LIMA, Jacqueline Cássia Pinheiro. Modernização e higienismo social: projetos de habitações populares em Recife e Rio de Janeiro durante o Estado Novo (1937-1945).Revista Espaço Acadêmico: nº 35, abril/2004.

LIMA, Lúcio Renato Mota. O apostolado dos patrões: limites e possibilidades de um plano industrial disciplinarreligioso em uma fábrica têxtil (Camaragibe, 1891 - 1908). Dissertação (Mestrado em História). Universidade Federal de Pernambuco, Recife, 2012.

MAIA, Pedro Américo. História das Congregações Marianas no Brasil. São Paulo: Loyola, 1992.

MÉLO FILHO, Lilian Renata de. O Centro Educativo Operário em Recife durante o Estado Novo (1937/1945): educação e religião no controle dos trabalhadores. Dissertação (Mestrado em Educação). Universidade Federal de Pernambuco, Recife, 2006.

OLIVEIRA, Valdemar; FILGUEIRA FILHO. Mocambo. Recife: s.n., 1940.

SILVA, Ana Carolina Miranda Paulino da. O Grupo Gente Nossa e o movimento teatral no Recife (1931 - 1939 ). Dissertação (Mestrado em História). Universidade Federal de Pernambuco, Recife, 2009.

Submissão: $13 / 05 / 2016$

Aceite: $16 / 06 / 2016$ 